\title{
Local Resources Based Empowerment Through Non-Formal Education for Women Communities in Kampung Babakan Cianjur
}

\author{
Mustangin $^{1, *}$
}

\author{
${ }^{1}$ Department of Non-Formal Education, Faculty of Teacher Training and Education, Universitas Mulawarman, \\ Samarinda, Indonesia \\ *Email: mustangin1992@gmail.com
}

\begin{abstract}
This study will examine further the process of empowerment based on local resources through non-formal education for women around the Citarum River. This study uses a descriptive qualitative approach because it is in accordance with the purpose of this study is to describe more in the process of community empowerment through non-formal education, in the activity of utilizing water hyacinth for handicrafts for women in Babakan Cianjur. The results of the study show that women empowerment through non-formal education with local resource-based training around the community is the use of water hyacinth for handicraft materials. The interesting thing is the existence of a shared library which is also present at Bangkit Bersama Cooperative which presents craft-themed books to add creativity. Based on the results of these studies, the community empowerment model that has been implemented in Bangkit Bersama Cooperative can be used as a reference for local resource-based empowerment models.
\end{abstract}

Keywords: local resources, non-formal education, training activity, women empowerment

\section{INTRODUCTION}

Indonesia is a developing country that has various problems, one of which is the problem at the level of poverty of the community. The Indonesian government has actually been trying to overcome this poverty problem, but these problems are still things that need to get more indepth study to find the right solution to overcome the problem of poverty.

The poverty rate based on the report has decreased, it shows that the efforts that have been carried out to overcome poverty are successful, but still need to be a major concern so that the Indonesian people can get out of poverty. The problem of poverty is the inability to fulfill life's needs or basic needs. Thus, the poor are residents who have an average monthly expenditure below the poverty line. The conclusion of this explanation is that poor people are people who are unable to meet basic needs. While basic needs are important needs to be fulfilled. If the basic needs are not fulfilled, the other needs cannot be fulfilled. So that the poor are people who live in poverty are people who are vulnerable to social problems.

The government through its programs has sought poverty reduction. However, this is still getting criticism because these government programs ignore the principle of community independence. For example community empowerment programs for poverty reduction with charity programs. Most of the programs in the field only focus on providing capital without paying attention to aspects of community dependence as program beneficiaries [1]. The philosophical foundation of the Indonesian people is in accordance with the fifth Pancasila namely social justice for all Indonesian people, this is one of the efforts in poverty alleviation namely charity programs, often not yet fair and evenly distributed in reality, have not gone well, including human resources, social responsibility and social assistance that are not well targeted means that they are not in line with the fifth philosophical foundation of the Indonesian nation [2]. Poverty reduction is one of the responsibilities of all parties not only through the role of the government. There needs to be good cooperation between the government, the private sector and the community itself as the target of poverty reduction programs.

Poverty alleviation can be implemented by implementing community empowerment programs. Community empowerment is an effort to increase the capacity of the community both men and women. Women empowerment aims to increase the capacity of women to help with their family's income or to improve their family's welfare for female household heads. Women or potential women to carry out various productive activities that produce and can help the family economy [3]. More broadly the national economy, moreover the potential is spread in various fields. With this potential, women have the potential to play an active role in the economic recovery process which is still shrouded in various problems. This is intended to give the community strength, but also access to resources is an effort to achieve the goal of Sustainable 
Livelihoods. Implementation of sustainable livelihoods begin with the ability to gain control of the natural resources that support them and maximize the potential of the surrounding environment and management of resources that benefit the poor community, because poor community are often in a very disadvantageous position [4]. Community empowerment that should be designed by analyzing the needs and utilization of existing resources in the community. The characteristics of women empowerment have been carried out by Bangkit Bersama Cooperative by empowering women in Kampung Babakan Cianjur. These women are women who live around the Citarum river with various problems, including poverty and environmental damage. Based on the results of preliminary interviews with the owners of the Revived Cooperative It is well known that the Kampung Babakan Cianjur is a village around the Citarum river which stores natural potential but is a place for garbage to accumulate and even the dirtiest river in the world plus water hyacinth weeds that cover the Saguling reservoir in the upstream Citarum poor cultural image and poverty problems of the people living on the outskirts of the Citarum River add to the poor condition of the Citarum River.

Local resource-based empowerment is an effort to increase the capacity of women to be able to use water hyacinth in order to make handicrafts that are worth selling, this is because many water hyacinth weeds are not utilized, causing environmental problems.The empowerment process can be carried out with non-formal education activities. Non-formal Education to empower is an educational approach that allows students to gain a greater understanding of control over social, economic, and / or political forces through: 1) high level practice control over all aspects of the learning process; 2) learn both "content" and "process" skills responsive to their needs and problems; and 3) work together to solve common problems [5]. The empowerment process through nonformal education based on this is an increase in the potential of women as targets. Non-formal education can function to develop women potential to master functional knowledge and skills and develop professional attitudes and personalities, so they can work and solve problems in their lives [6]. Based on this matter, this study will examine the local resource-based community empowerment through non-formal education by utilizing water hyacinth.

\section{RESEARCH METHOD}

This study uses a descriptive method with a qualitative approach. Reason The qualitative approach was chosen as the approach in the study because it was in accordance with the purpose of this study to analyze in detail about local resource-based empowerment through the use of water hyacinth for handicrafts for women in Kampung Babakan Cihampelas. Conducting qualitative research needs to examine complex problems in addition to needing a more detailed understanding of the topics raised in the study [7]. Therefore, more specific data collection requires in-depth data mining about community empowerment in empowering these women. The research method is using descriptive methods, because in this study will describe the empowerment of women in Kampung Babakan Cianjur based on local resources through the use of water hyacinth as a craft material.

Data collection is the most strategic step in research. This is because the main purpose of the research is to obtain data. The main collection techniques are interviews through extracting information by asking questions with informants. In this study the main informants were the heads of Bangkit Bersama Cooperatives and female craftsmen who were divided into female craftsmen who were also facilitators and craftsmen who gained knowledge from the facilitator. The second collection technique is observation. Observations made were carrying out observations of community characteristics, the process of making handicrafts made from water hyacinth and the results of the community empowerment program that had been carried out. Observations in this study were to support the main data obtained from interviews so that the data obtained would be more accurate. Subsequent data collection is through document studies in the form of conducting studies on documents related to the research to be conducted. The type of data to be collected through the study of this document is data in the form of written sources and photographs of program activities. Study documents in this study to strengthen data from interviews and observations so as to obtain more accurate data.

The data analysis technique in this study is divided into three steps including Data Reduction, Data Display, dan Conclusion Drawing [8]. Data obtained from the interview is raw data. Next the researcher sorted out the data collected. After the data has been sorted, the researcher encodes the data, meaning that it encodes the data using symbols, based on the informant and the interview time to make it easier to find data. Data that has been coded, then adjusted to the focus of the study. After the data has been sorted and adjusted to the focus of the research, the researcher presents the data. The researcher presents meaningful data in the form of narratives or descriptions that are easier to understand and more communicative. After the data is presented the researcher draws the initial conclusions based on the findings of the data. After the data is verified based on evidence that is strong and consistent with the conditions at the time of the study, the researcher draws conclusions as final conclusions according to the stated research objectives.

In this study, the validity test technique was Data Triangulation. The researcher checks every data obtained through in-depth interviews, then cross checks. The triangulation carried out by the researcher was Trianggulation Source and Triangulation Technique. Triangulation Source is comparing the results of interviews from one informant with other informants. In the results of interviews conducted by the heads of cooperatives, they will rise together and will be adapted to the results of interviews with female craftsmen who are divided into female craftsmen who are also facilitators and female craftsmen who gain knowledge from the owners 
and facilitators. Triangulation technique is checking data based on different data collection techniques, this is done by checking the results of interviews, observation and study documents.

\section{RESULTS AND DISCUSSION}

\subsection{Profile of Bangkit Bersama Cooperative}

The idea of forming this cooperative came from concerns about environmental damage in the Saguling reservoir because of the piles of plastic waste, water hyacinth weeds and increasingly shallow saguling reservoirs due to the continuous sedimentation rate entering the inlate saguling which resulted in siltation of the reservoir. in addition, the social problems of the people living around the reservoir are those belonging to the category of the poor. So that an idea was born to build a mutualism symbiosis between the empowerment of communities around the reservoir and the preservation of the environment of the Saguling reservoir through community-based financial institutions, namely Bangkit Bersama Cooperatives. In 2009 a Cooperative called Bangkit Bersama Cooperative was born, where the members were community members who were scavengers and poor people living around the Saguling reservoir.

Since 2009 Bangkit Bersama Cooperative, aside from being a financial institution, has also developed a program to empower garbage collectors and women in the Citarum River, this program has been proven to be able to reduce the volume of waste in the Citarum River while creating new jobs and increasing the income of the community in the Saguling reservoir area. The positive correlation of the two problems turned out to produce a solution that has a positive effect on the environment and the welfare of the community where by utilizing waste, water hyacinth weeds and critical land to be more productive not only can preserve the saguling reservoir environment, but can prosper the community living around the reservoir.

Bangkit Bersama Cooperative was established in 2009, and officially incorporated in 2011 with the Notarial Establishment Deed Number 1 dated December 1, 2011, and authorized by The Ministry of Cooperative and Small Medium Enterprises. of the Republic of Indonesia number 120/BH/XIII.26/ 518-KOP/I/2012. Based on this, Bangkit Bersama Cooperative to become one of the cooperatives which has a clear legal entity.

The scope of community empowerment activities by Bangkit Bersama Cooperative is to develop a business for recycling plastic waste in the Saguling reservoir, developing a water hyacinth craft business by utilizing water hyacinth weeds in the saguling reservoir, Developing the Saguling Community Forest business by planting trees around the Citarum riverbank, developing training needs community life, advocating for the community to policy makers at the regional level as well as the central government. Conduct publications, socialization and awareness of the public regarding the preservation of the Citarum river environment both in print, television and social media.

\subsection{Local Resource Based Woman Empowerment}

Women living in Kampung Babakan Cianjur, are women who live around the Citarum River. Based on the background of the problem described above, it is known that the Citarum River is one of the rivers with serious environmental problems because it has a lot of garbage and water hyacinth weeds that cover the surface of the reservoir. In addition to the many wild water hyacinth weeds that also make the Citarum river environment a problem. Water hyacinth is a local potential that can be used as raw material for various handicrafts that have a value in selling. Local potential by Bangkit Bersama Cooperative is one of the ways to empower women from poor families, in the Kampung Babakan Cianjur so that these women need additional income to help their basic daily needs. Women empowerment is a solution to overcome these problems. Women empowerment is an effort to increase the ability, skills, and attitudes so that they are able to meet basic needs to meet their living needs properly [9]. Women empowerment as a process of change by which women with limited resources, freedom, and power are enabled to gain stronger autonomy to enhance their ability to exercise decision-making and freedom in ways that can positively contribute to their development and well-being [10]. empowerment needs to be done for women as a great potential in boosting the quality of life and poverty alleviation [11]. Therefore, Bangkit Bersama Cooperative to implement a women empowerment program through the use of water hyacinth for handicrafts. So that the women involved in the program received an increase in income.

The utilization of Hyacinth for various handicrafts is one form of problem-based empowerment and local resources. As described in the previous discussion, water hyacinth that is not utilized will be a problem, one of which is environmental problems. The Hyacinth Weed can be easily found in the village of Babakan Cianjur so that it can be used as a basis for empowerment based on local potential.

The community there are resources that have the potential to increase welfare, but this potential may not be used properly so that it cannot be used to improve community welfare [12]. The working of the community empowerment interventon model solving problems to achieve a particular goal through determining the needs and problems faced by local communities, individuals, groups, prioritizing problems and needs, making plans for meetings that need to be based on potential local sources [13]. The Hyacinth Weed before there is a community empowerment program by Bangkit Bersama Cooperative that has not been fully utilized, giving rise to serious environmental problems to overcome. the use of water hyacinth for various handicrafts is the solution to 
overcome environmental problems as well as utilized resources for the welfare of women in Kampung Babakan Cianjur.

\subsection{The Women Empowerment Through Non- Formal Education}

Women empowerment through non-formal education that occurs in women in Kampung Babakan Cianjur is an effort to increase women power in Kampung Babakan Cianjur through non-formal education program activities. Empowerment does not merely provide authority or power, in empowerment the meaning of the educational process is in improving the quality of individuals, groups, or communities [11]. Women empowerment is an educational activity that aims to develop the capacity of women to be able to become women who have the ability to overcome poverty problems and improve the quality of their families.

Women empowerment through non-formal education in Kampung Babakan Cianjur is education for women empowerment through the use of water hyacinth as a local potential that exists in Kampung Babakan Cianjur. The previous explanation is that women in Kampung Babakan Cianjur are women who live in poverty besides their environmental conditions around the Citarum River which grow a lot of Hyacinth Weeds which adds to the poor quality of people's lives. Therefore a non-formal education program is needed to empower women in Kampung Babakan Cianjur.

Women empowerment through non-formal education is a process to increase women capacity, based on this, the stages that are needed are mature to get maximum results. Empowerment is a process that requires time, so that it is carried out in stages and continuously [11]. Based on this, the results of research on the process of women empowerment through non-formal education in Kampung Babakan Cianjur in this study are translated into the analysis of the stages of implementation as follows:

a. Planning: The initial stage of a program is the planning stage, which in this stage consists of various processes to prepare all equipment before the implementation of the program. The stages of planning carried out by Bangkit Bersama Cooperative for the women empowerment program include activities to identify needs, problems, and potential that can be developed by women. So that from this planning activity a local resource-based women empowerment program was formed. The planning process was also carried out with local local participants such as community leaders, institutions in the community such as Karang Taruna, Posyandu, Majelis Taklim and other local associations.

b. Implementation: is the process of ensuring the human and physical needs of each available resource to carry out the plan and achieve the stated objectives. In this study the implementation of local resource-based women empowerment was carried out into several stages of activities, including the following:

- The team from the cooperative rises together to form Local Cadres, for the next local cadre who moves to organize other communities.

- These local cadres were previously equipped with the use of water hyacinth skills to train women who would be involved in local resource-based women empowerment activities.

- The process of mobilizing women is carried out directly by the Team from the cooperative to rise together which involves the Cadres who have been selected by the Team. By involving the role of local cadres will facilitate the achievement of community empowerment programs. It is this local cadre who trains other women involved in this local resource-based women empowerment.

- In addition to training on making hyacinthbased handicrafts, the women were facilitated by a shared library that had a collection of books on crafts that could be used by these women to learn

c. Monitoring and Evaluation: after the program runs, the next stage is the program monitoring and evaluation stages. This stage is to analyze the progress of women empowerment based on local resources as well as assessing the implementation of the program whether it runs according to the procedure and the expected results match the expected goals. The process of monitoring and evaluation based on the results of this study can be described as follows:

- In this case, control and supervision are carried out directly by the Owner of Bangkit Bersama Cooperative and assisted by local cadres who have been previously appointed.

- Evaluation is an effort made by an institution to assess whether a program is successful or not. All activities included in the community empowerment program carried out by the Internal Team in addition to the evaluation also involved experts as external parties trusted by Bangkit Bersama Cooperative to assess the success of the program. One aspect that is assessed from the program is on behavioral changes that occur in the target community of community empowerment programs. 
[5] S. Kindervatter, Non-Formal Education as an Empowering Process with Case Studies from Indonesia and Thailand. Amherst Massachusetts: Centre for International Education, University of Massachusetts, 1979.

[6] L. M. Ganiem, "Pemberdayaan Perempuan Miskin Kota Melalui Pendidikan,” J. ASPIKOM, vol. 3, no. 2, 2017.

[7] J. . Creswell, Qualitative Inquiry \& Research Design: Choosing Among Five Approaches, 3rd ed. Thousand Oaks, CA: SAGE Publication, 2013.

[8] M. B. Miles and H. A.M, Qualitative Data analysis, 2nd ed. USA: SAGE Publications, 1994.

[9] O. N. Putri, R. S. Darwis, and G. G. K. Basar, "Pemberdayaan Perempuan Kepala Keluarga," in Prosiding KS, 2015.

[10] T. Sulistyowati, "Model Pemberdayaan Perempuan dalam Meningkatkan Profesionalitas dan Daya Saing untuk Menghadapi Komersialisasi Dunia Kerja," J. Peremp. dan Anak, vol. 1, no. 1, pp. 1-11, 2015.

[11] O. . Anwas, Pemberdayaan Masyarakat di Era Global. Bandung: Alfabeta, 2013.

[12] Soetomo, Keswadayaan Masyarakat: Manifestasi Kapasitas Masyarakat Untuk Berkembang Secara Mandiri. Yogyakarta: Pustaka Pelajar, 2002.

[13] Mustangin, D. Kusniawati, N. P. Islami, B. Setyaningrum, and E. Prasetyawati, "Pemberdayaan Masyarakat Berbasis Potensi Lokal Melalui Program Desa Wisata di Desa Bumiaji," J. Pemikir. dan Penelit. Sosiol., vol. 2, no. 1, pp. 59-72, 2017.

\section{REFERENCES}

[1] F. I. N. Harahap, "Pemberdayaan Masyarakat Pemulung Sampah Sungai Citarum Melalui Koperasi Bangkit Bersama," J. Pendidik. dan Pemberdaya. Masy., vol. 4, no. 2, pp. 180-186, 2017.

[2] S. Y. Pertiwi, "Model Kebijakan Pemerintah Daerah dalam Penanggulangan Kemiskinan," J. Pandecta, vol. 9, no. 2, 2014.

[3] O. Sukmana, "Konsep Pemberdayaan Masyarakat Melalui Pengembangan Komunitas Berbasis Potensi Lokal," J. Humanit., vol. 6, no. 1, pp. 59-64, 2010.

[4] F. Nazarullail, Hardika, and E. S. Desyanty, "Pemberdayaan Masyarakat Melalui Program ekowisata 'Lepen Adventure,'” J. Pendidik., vol. 2, no. 8, pp. 10711076, 2017. 